\title{
Primary cardiac lymphoma (PCL) - diagnostic difficulties
}

\author{
Karolina Skalec ${ }^{1}$, Linda Litwin ${ }^{1}$, Katarzyna Drozdz ${ }^{1}$, Pawel Gac ${ }^{2}$, Przemyslaw Jazwiec ${ }^{2}$, \\ Mariusz Chabowski ${ }^{3}$, Robert Zymlinski ${ }^{4}$, Wlodzimierz Molenda ${ }^{1}$, Andrzej Szuba ${ }^{5}$, Dariusz Janczak ${ }^{5}$ \\ ${ }^{1}$ Department of Internal Medicine, $4^{\text {th }}$ Military Teaching Hospital, Wroclaw, Poland \\ ${ }^{2}$ Department of Radiology and Diagnostic Imaging, $4^{\text {th }}$ Military Teaching Hospital, Wroclaw, Poland \\ ${ }^{3}$ Department of Surgery, $4^{\text {th }}$ Military Teaching Hospital, Wroclaw, Poland \\ ${ }^{4}$ Department of Cardiology, $4^{\text {th }}$ Military Teaching Hospital, Wroclaw, Poland \\ ${ }^{5}$ Faculty of Health Science, Wroclaw Medical University, Wroclaw, Poland \\ Kardiochirurgia i Torakochirurgia Polska 2015; 12 (3): 266-268
}

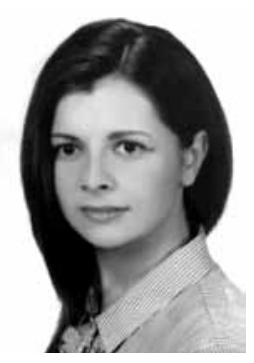

\begin{abstract}
Primary cardiac lymphoma $(\mathrm{PCL})$ is the very rare disease that is associated with a high mortality rate. A prompt and proper diagnosis may affect the prognosis, and proper treatment may improve life expectancy. This report documents the case of a 74-year-old female with primary cardiac lymphoma. Unfortunately, the patient died from heart failure on her $23^{\text {rd }}$ day in hospital.
\end{abstract}

Key words: primary cardiac lymphoma, heart tumour, echocardiography.

\section{Introduction}

Primary cardiac neoplasms are rare, with an incidence of $0.056 \%$ of all tumours seen in autopsies. Twenty-five percent of these cardiac neoplasms are malignant [1, 2]. Primary cardiac lymphoma (PCL) constitutes $5-6 \%$ of primary cardiac malignant neoplasms [1,3]. Because of its rapid progress, late diagnosis due to its non-specific symptoms and variable patient responses to treatment, the prognosis for patients with $\mathrm{PCL}$ remains poor. Complete remissions have been reported, although the longest period of survival has not exceeded 144 weeks [4]. Approximately $80 \%$ of patients live less than 12 months after diagnosis [5].

\section{Case report}

A 74-year-old woman was admitted to the Department of Internal Medicine because of exertional dyspnoea and a fever which had lasted for two months. On admission, the physical examination revealed nothing remarkable except for an elevated body temperature $\left(37.6^{\circ} \mathrm{C}\right)$. Abnormalities in the laboratory test results included: $\mathrm{Hb} 10.5 \mathrm{~g} / \mathrm{dl}$, WBC $10.6 \times 10^{9} /$, CRP $71 \mathrm{mg} / \mathrm{l}$, ESR 47/86 mm, total bilirubin

\section{Streszczenie}

Pierwotny chłoniak serca jest rzadkim schorzeniem, charakteryzującym się wysoką śmiertelnością. Rokowanie poprawia szybka i właściwa diagnoza oraz leczenie. W pracy przedstawiono przypadek 74-letniej pacjentki z pierwotnym chłoniakiem serca. Niestety, kobieta zmarła w 23. dobie pobytu szpitalnego w przebiegu niewydolności serca.

Słowa kluczowe: pierwotny chłoniak serca, guz serca, echokardiografia.

$1.89 \mathrm{mg} / \mathrm{dl}$, AST $46 \mathrm{IU} / \mathrm{l}$, ALT $74 \mathrm{IU} / \mathrm{l}$, and GGTP $128 \mathrm{IU} / \mathrm{l}$. An electrocardiogram showed a sinus rhythm of $90 / \mathrm{min}$, and negative T-waves in II, III, aVF, and V3-V6. The chest $X$-ray revealed cardiomegaly. Both the transthoracic (TTE) and the transoesophageal (TEE) echocardiographs indicated the presence of a large right-atrial tumour (Fig. 1). A computed tomography (CT) of the heart and large vessels revealed a polycyclic, infiltrating nodular mass with nonhomogenous enhancement after contrast administration encompassing the right atrium, right ventricle, and in the pericardial sac with pericardial effusion, with an associated mediastinal lymphadenopathy (Fig. 2A and 2B). Three months earlier the patient had been hospitalised in the Department of Cardiology due to atrial fibrillation. At that time, the TTE did not show any of the right-sided masses.

With a presumptive diagnosis of a cardiac sarcoma or lymphoma, the patient was disqualified from pericardiocentesis due to the presence of the tumour mass at the puncture site, and from a transjugular biopsy due to the extensive thrombosis of both jugular veins. A transcervical mediastinoscopy was performed under general anaesthetic, and several lymph node stations (3, 4R, 4L and $10 \mathrm{R})$

Address for correspondence: Mariusz Chabowski, Department of Surgery, $4^{\text {th }}$ Military Teaching Hospital, 5 Weigla St., 50-981 Wroclaw, Poland, phone: +48261660247 , fax: 48717660245, e-mail: mariusz.chabowski@gmail.com 
were biopsied. The pathological examination only revealed chronic lymphadenitis. The patient's condition gradually deteriorated and she died from heart failure on her $23^{\text {rd }}$ day in hospital. An autopsy was performed and the postmortem examination of the tumour revealed a cardiac B-cell lymphoma.

\section{Discussion}

A primary cardiac lymphoma is defined as a non-Hodgkin's lymphoma involving only the heart and/or pericardium or a lymphoma with the bulk of the tumour within the heart $[6,7]$. More than $50 \%$ of patients with $P C L$ suffer from heart failure that is unresponsive to therapy. The classic symptoms of PCL include dyspnoea, oedema, weakness and fatigue, pericardial effusion, arrhythmia, chest pain, weight loss, fever, and night sweats $[4,7]$. Due to the low prevalence of PCL, its treatment is not established. Treatment approaches include combinations of: chemotherapy, radiotherapy, autologous stem cell transplant, and tumour mass resection [4]. The median of the survival range is from 1.5 months with the surgical approach to 26.5 months with chemotherapy combined with radiotherapy [4]. The average survival rate is extremely short in untreated patients [4].

The procedures aimed at establishing a diagnosis vary considerably in sensitivity and invasiveness. In the case documented here, a mediastinoscopy with lymph node sampling was performed, but it only revealed chronic inflammation. In view of the high risk of heart failure, other procedures could not be performed. There are two descriptions of a similar diagnostic path; in both cases a mediastinoscopy yielded the diagnosis [7, 8]. Some procedures, such as an open-heart biopsy, have $100 \%$ sensitivity but are associated with a high risk of serious complications in patients with uncontrolled heart failure [4, 7]. Pericardial

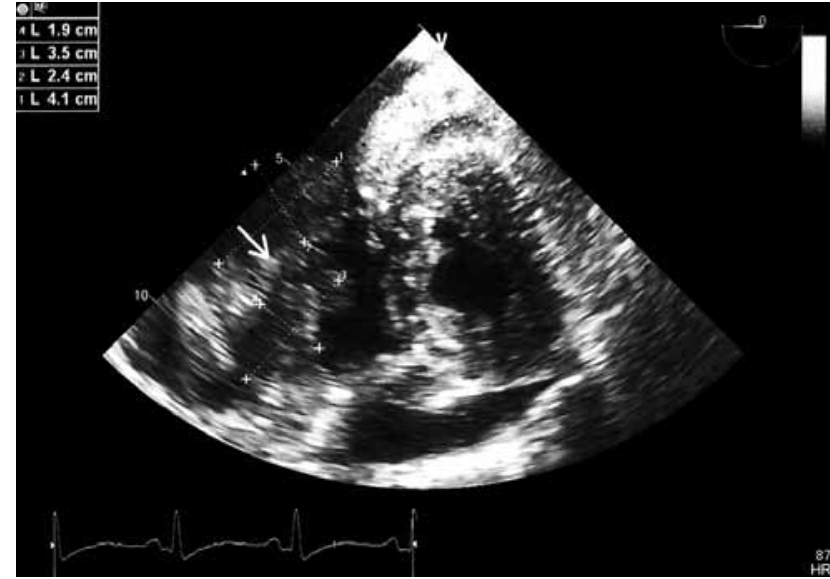

Fig. 1. Transoesophageal echocardiography - obliteration of the right atrium by the structure of echogenicity similar to the myocardium, causing obstruction of the tricuspid valve and descending to the right ventricle

cytology is diagnostically effective in $60-67 \%$ of cases, but pericardial effusion is only present in $12-49 \%$ of patients $[4,7,9]$. A pericardial biopsy has a reported diagnostic yield of $38-50 \%[7,9]$. There are individual reports of other procedures used to diagnose PCL such as transoesophageal ultrasound-guided biopsy, transvenous endomyocardial biopsy, percutaneous intracardiac biopsy with combined fluoroscopy, and transoesophageal echocardiographs [6, 9]. Their sensitivity remains unproven.

\section{Conclusions}

In conclusion, prompt diagnosis and treatment management maximise prolonged survival in PCL. Therefore, the appropriate choice of diagnostic procedure influences the patient's prognosis $[2,4,9]$. Unfortunately, the range of
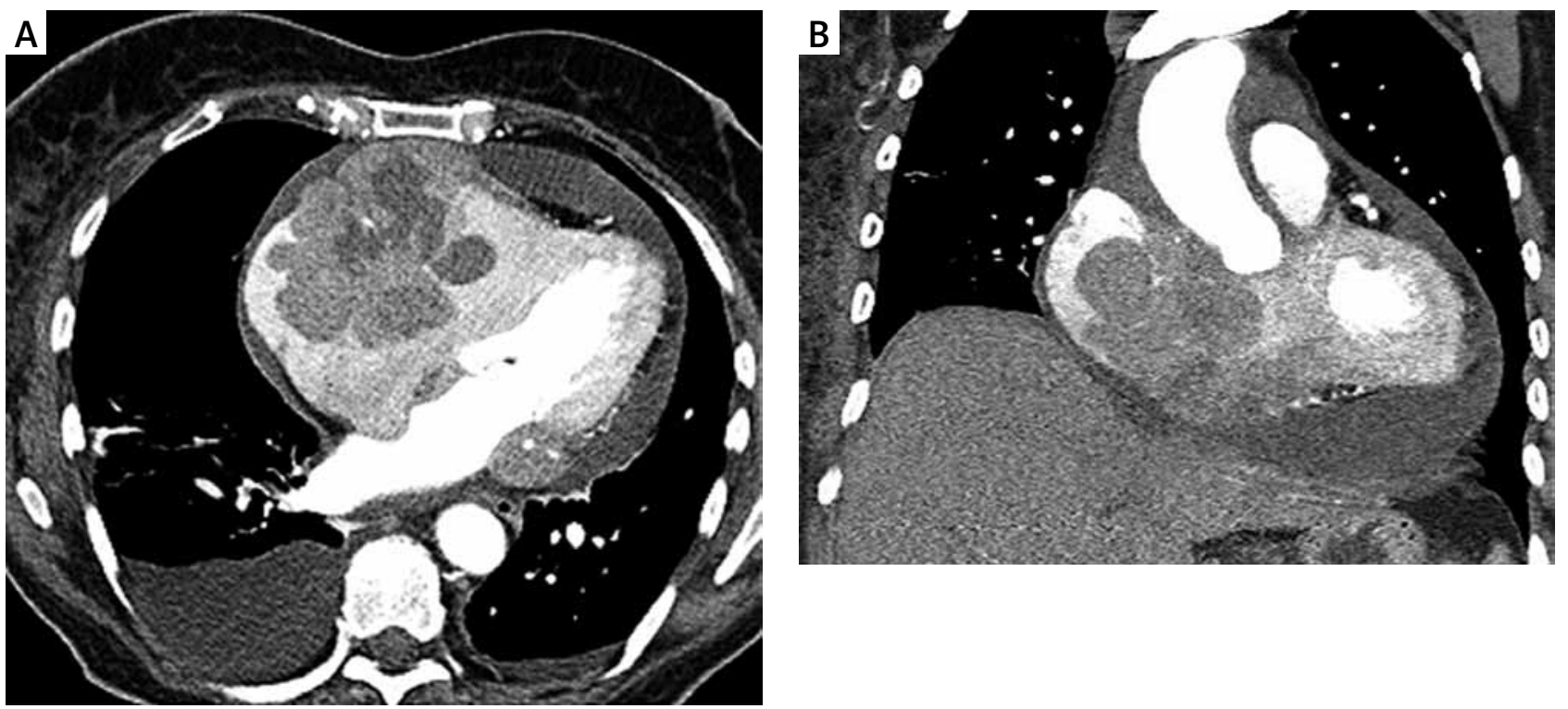

Fig. 2. Computed tomography of the heart and large vessels: a polycyclic, non-measurable, infiltrating nodular mass undergoing nonhomogenous enhancement in the cavity of the right atrium, extending into the right ventricle, pericardium, and myocardium of the left atrium. There is also a pericardial effusion. A) Multiplanar reconstrucion - axial view. B) Multiplanar reconstrucion - anterior view 
modern diagnostic approaches may be seriously limited in an advanced stage of PCL and when a patient's condition on admission is critical.

\section{Disclosure}

Authors report no conflict of interest.

\section{References}

1. Neragi-Miandoab S, Kim J, Vlahakes G. Malignant tumours of the heart: a review of tumour type, diagnosis and therapy. Clin Oncol 2007; 19: 748-756.

2. Nascimento AF, Winters GL, Pinkus GS. Primary cardiac lymphoma: clinical, histologic, immunophenotypic, and genotypic features of 5 cases of a rare disorder. Am J Surg Pathol 2007; 31: 1344-1350.
3. William CR. Primary and secondary neoplasms of the heart. Am J Cardiol 1997; 80: 671-682.

4. Anghel G, Zoli V, Petti N, Remotti D, Feccia M, Pino P, Majolino I. Primary cardiac lymphoma: report of two cases occurring in immunocompetent subjects. Leuk Lymphoma 2004; 45: 781-788.

5. Ikeda H, Nakamura S, Nishimaki H, Masuda K, Takeo T, Kasai K, Ohashi T, Sakamoto N, Wakida Y, Itoh G. Primary lymphoma of the heart: case report and literature review. Pathol Int 2004; 54: 187-195.

6. Rolla G, Bertero MT, Pastena G, Tartaglia N, Corradi F, Casabona R, Motta M, Caligaris-Cappio F. Primary lymphoma of the heart. A case report and review of the literature. Leuk Res 2002; 26: 117-120.

7. Ceresoli GL, Ferreri AJM, Bucci E, Ripa C, Ponzoni M, Villa E. Primary cardiac lymphoma in immunocompetent patients. Cancer 1997; 80: 1497-1506.

8. Bambury R, Gallagher F, Dodd JD, Fennelly D. Primary cardiac lymphoma: diagnostic tools and treatment challenges. Ir J Med Sci 2011; 180: 271-273.

9. Chalabreysse L, Berger F, Loire R, Devouassoux G, Cordier J, Thivolet-Bejui F. Primary cardiac lymphoma in immunocompetent patients: a report of three cases and review of the literature. Virchows Archiv 2002; 441: 456-461. 